\title{
Thrombolysis for acute ischemic stroke: experience in Dubai, and comparison of Arab with Non-Arab Population
}

\begin{abstract}
Background: Intravenous alteplase is now the standard of care for treatment of acute ischemic stroke. Rashid Hospital was the first hospital in Dubai, UAE to start giving intravenous alteplase. Our objective is to present our experience with patients thrombolysed and to evaluate the differences between Arab and non-Arab patients.

Methods: In a prospective manner, all subjects presenting to Rashid Hospital emergency and receiving intravenous thrombolysis were identified. Data was collected on demographics, stroke severity, risk factors, and outcomes. Comparisons were made between Arab and non-Arab patients in terms of risk factors and outcomes. SPSS 20 was used for analysis and p-value of 0.05 was considered significant.

Results: A total of 176 patients were thrombolysed during the study period. The mean age of the patients was 50.83 (SD 14.10) and $82.8 \%$ were males. $22.2 \%$ of the patients were of Arab origin and $62.5 \%$ were of South Asian origin. Mean Door to needle time was 64.14 minutes (SD 24.02). Hypertension was the commonest risk factor (54.6\%). Mean NIHSS at presentation was 11.84 (SD 4.29). Twelve patients (6.9\%) developed post thrombolysis symptomatic intracerebral hemorrhage. Ten patients $(5.7 \%)$ died in the hospital.

Patients of Arab origin were significantly older at stroke onset, and had higher proportions of major vascular risk factors. There were no differences in the safety and efficacy outcomes in the two ethnic groups

Conclusion: Compared to international data, use of intravenous thrombolysis was safe and effective. Arab patients differ in age and risk factor profile from their non-Arab counterparts
\end{abstract}

Keywords: Stroke, Thrombolysis, Hemorrhage, Arabs, Outcomes
Volume 4 Issue $6-2016$

\author{
Maria Khan, Husnain Hashim, Zebun Nisa, \\ Syed Habibullah Kamran, Suhail Alrukn \\ Department of Neurology, Rashid Hospital, UAE
}

\begin{abstract}
Correspondence: Maria Khan, Department of Neurology, Rashid Hospital, Postal Address:Villa number 178, Esmeralda, Victory Heights, Dubai Sports City, Dubai, UAE, Tel 971502280297,Email mhkhan.junaidi@gmail.com
\end{abstract}

Received: March 20, 2016 | Published: May 23, 2016
Abbreviations: UAE, United Arab Emirates; NINDS rtPA, Neurological Disorders and Stroke recombinant tissue plasminogen activator; tPA, tissue Plasminogen Activator; CT, Computerized Tomography; mRS, modified Rankin Scale; TOAST, Trial of Org 10172 in Acute Stroke Treatment criteria; NIHSS, National Institute of Health Stroke Scale; SPSS, Statistical Package for Social Sciences; IQR, Interquartile range; OTT, Onset to treatment time

\section{Introduction}

Stroke is a significant cause of morbidity and mortality in the developing Arab world. A systematic review from 2009 highlighted the dearth of sound epidemiological data from these countries. ${ }^{1}$ More recently a review on temporal trends suggested a rise in stroke incidence in Asian countries, an earlier age at onset, and a relative increase in ischemic stroke subtypes. ${ }^{2}$ There is reason to believe that since Arab countries are in a similar stage of epidemiological transition as other Asian countries, they would be sharing these trends as well. United Arab Emirates (UAE) is no exception. Results from a population based screening program demonstrate a very high cardiovascular risk factor prevalence especially of diabetes and obesity. ${ }^{3}$ Judging from this, it is expected that the burden of stroke would also be substantial.

Ever since the National Institute of Neurological Disorders and Stroke recombinant tissue plasminogen activator (NINDS rtPA) trial followed by its approval in 1996, intravenous thrombolysis has remained the standard of care for acute ischemic stroke patients. ${ }^{4}$ The window has also since been extended from 3 hours to 4.5 hours. ${ }^{5}$ Despite its proven benefits, the intervention remains under-utilized in most parts of the world. Reasons for this include lack of proper set-up for administration, decreased awareness regarding the intervention and hence delayed presentations, and lack of properly trained physicians to administer and take care of these patients.

Utilization of intravenous tissue plasminogen activator (tPA) is very poor in the Arab world as well. An article published in 2011 showed that even in a large country like Saudi Arabia, only seven out of 350 hospitals provide thrombolysis for acute stroke, and the average number of patients thrombolysed per year is merely $50 .{ }^{6}$ Another study from six large stroke centers in the Arabian peninsula ${ }^{7}$ showed that a mere $0.8 \%$ of the 780 ischemic stroke cases were thrombolysed during the study period, a number too small to make any meaningful conclusion regarding the efficacy and safety of the intervention in this population.

Dubai is the most populous city of UAE and Rashid Hospital is the city's largest public sector hospital with one of the busiest emergencies in the country. Despite seeing a substantial number of stroke cases every year, intravenous thrombolysis was not being utilized up until 2009. Even after that, the number of patients thrombolysed was very small. In 2011, the stroke unit at Rashid Hospital, Dubai was set up. The number of patients being thrombolysed per year has steadily gone up since then.

The objectives of our study were two fold. First, to describe the number and proportion of stroke patients treated with intravenous thrombolysis, their demographic characteristics, time to treatment, outcomes and complications; second to compare Arab with non- 
Arab ethnic groups in terms of stroke risk factors and outcomes of thrombolysis as measured by modified Rankin Scale.

\section{Methods}

All patients treated with intravenous thrombolysis within 4.5 hours of symptom onset, by the stroke team at Rashid hospital between September 1, 2011 and August 31, 2014 were prospectively identified. Our stroke team consists of consultants and specialist registrars who rotate on 'first call' to respond immediately to stroke code and provide this coverage round the clock, seven days a week. In addition, there is a dedicated 4 bed stroke unit with nurses trained in care of acute stroke cases, post thrombolysis. Since the establishment of the stroke service, periodic educational training sessions have been held by our stroke team, to orient the emergency staff in quick identification of acute stroke and the steps necessary to ensure timely administration of thrombolysis, including generation of stroke code and expediting Computerized Tomography (CT) scanning.

For the purpose of this study, trained personnel recruited these acute stroke patients prospectively through clinical identification. Stroke was defined as "rapidly developing clinical signs of focal (or global) disturbance of cerebral function, lasting more than 24 hours or leading to death, with no apparent cause other than that of vascular origin.". ${ }^{8}$ All patients underwent Computerized Tomography (CT) imaging which supported the diagnosis of ischemic stroke and ruled out intracranial hemorrhage. In addition, the stroke unit log was checked on a biweekly basis, since all thrombolysed patients get admitted to this unit. This was done to ensure that no cases are missed.

The following information was recorded on a pre-designed questionnaire: date of birth, ethnicity, gender, baseline functional status (as per modified Rankin Scale-mRS) time of stroke onset, time of arrival to emergency, time of CT imaging, and time of tPA administration. Data was also collected on post tPA complications, in-hospital mortality and risk factors. This included, information on known diabetes, hypertension, dyslipidemia, ischemic heart disease, tobacco use and atrial fibrillation. Patients were labeled diabetic if they were known with the condition or had elevated $\mathrm{HbAlc}$ on admission. Hypertension was diagnosed if patients had known history of elevated blood pressure or if they were on anti-hypertensive medications. Dyslipidemia was diagnosed if patient had a total cholesterol of $>220 \mathrm{mg} / \mathrm{dL}$ or was on lipid lowering medications. Atrial fibrillation was diagnosed based on ECG tracing in the hospital or if a patient was known with the condition. Strokes were sub typed using the Trial of Org 10172 in Acute Stroke Treatment criteria (TOAST). ${ }^{9}$

Clinical outcomes were measured by National Institute of Health Stroke Scale (NIHSS score) ${ }^{10}$ and Modified Rankin Scale score, $\mathrm{mRS}^{11}$ at presentation, at 72 hours and at discharge. $\mathrm{mRS}$ was also assessed by telephonic follow up at 3 months post stroke onset when possible. mRS measures functional dependence on a scale of 0 (completely independent) to 6 (death). NIHSS is a quantitative measure of neurological deficits based on examination. When not documented, an NIHSS score as well as mRS score were obtained by inference using the clinical data in the neurology case record.

Primary Safety outcome was symptomatic intracranial hemorrhage as per the ECASS II definition. ${ }^{12}$ This is defined as clinical deterioration on NIHSS scale of 4 or more associated with intracranial hemorrhage on repeat CT scan within 24 hours of receiving thrombolysis. Other safety outcomes included serious systemic hemorrhage defined as extracranial bleeding considered to be life-threatening by the treating physician.
We took permission from the Ethical Review committee at Rashid hospital for this data collection. To maintain confidentiality, all patient data was coded and de-identified before analysis.

\section{Statistical analysis}

Data was analyzed using SPSS (Statistical Package for the Social Sciences) version 20. Mean \pm Standard deviation, and medians with interquartile range (IQR) are reported for continuous variables, and proportions for categorical variables. Comparisons were made between Arabs and non Arabs with respect to basic demographic characteristics, stroke severity and type, and safety and efficacy outcomes. Independent sample t-test was used to compare various continuous variables and chi square test for comparing categorical variables between groups. We also analyzed the various time components across the three years, using one-way ANOVA. p-value of 0.05 or less was considered significant.

\section{Results}

\section{Section I: Demographics and outcomes of thrombolysed patients}

A total of 176 patients received intravenous thrombolysis between September 1, 2011 and August 31, 2014. Of these only one patient was wrongly thrombolysed and he was eventually diagnosed as having brainstem encephalitis. Mean age of our patients was 50.84 (SD 14.17, range 22-84 years) years and $83.5 \%$ were men. Almost two thirds of the patients $(62.1 \%)$ were of South Asian origin, followed by Arabs (17.5\%) and Far East Asians (10.2\%). 145 patients $(82.4 \%)$ presented via Emergency Medical Services and the median onset to door time was 80 minutes (IQR 60-115 minutes). Median door to needle time for all patients was 60 minutes (IQR 55-77). Small vessel strokes were the commonest subtype $(31.1 \%)$, followed by cardioembolic $(20.9 \%)$ and large artery strokes (17.5\%). Forty eight $(27.4 \%)$ patients had strokes of undetermined etiology. Hypertension was the most common risk factor reported by 95 of the thrombolysed patients $(54.2 \%)$ followed by dyslipidemia and smoking. A quarter of the patients were diabetic and ten percent had history of prior stroke. Table 1 demonstrates the demographic and risk factor profiles of the thrombolysed patients.

Pre-treatment mean NIHSS was 11.9 points (SD 4.33, Median 12, IQR 9-15). Seven patients had intra-arterial thrombolysis and six of these also required mechanical thrombectomy. At discharge, $71.2 \%$ of the thrombolysed patients had a good functional outcome defined as an $\mathrm{mRS}$ of 2 or less. The median NIHSS had also improved to 4 (IQR $2-8)$ at discharge. When safety outcomes were analyzed, $12(6.8 \%)$ of the 176 subjects had symptomatic intracranial hemorrhage of which four died in hospital and another three required decompressive surgery. None of the subjects had life threatening extracranial bleeds. Nineteen subjects had malignant Middle Cerebral artery infarctions, of which 10 required decompressive surgery. Twelve patients died during a hospital stay (6.8\%). The efficacy and safety outcomes are shown in Table 2.

\section{Section 2: Comparison of Arabs with Non-Arabs}

We compared the demographic and risk factor profiles of Arabs with non-Arabs and found significant differences between the two groups. Patients of Arab origin were older at stroke onset ( $56.3 \pm 14.65$ years versus $49.7 \pm 13.8$ years, $\mathrm{p}=0.02$ ) and a significantly higher proportion had hypertension $(77.4 \%$ versus $50 \%$, p-value 0.005$)$, dyslipidemia $(54.8 \%$ versus $35.2 \%$, p-value 0.04$)$ and diabetes ( $45.2 \%$ versus $20.4 \%$, p-value 0.004 ), compared to their non-Arab 
counterparts. Stroke severity, time to treatment and its components, safety and efficacy outcomes were comparable between the two groups.

\section{Section 3: Performance of Stroke Service over 3 years}

We also analyzed the performance of our stroke service over the three years after introduction of intravenous thrombolysis. Table 3 demonstrates the various time components across the three years. There was a statistically significant improvement in all time components, with the mean door to needle time improving from 78.9 minutes in the first year to 57.4 minutes in the third year of our thrombolysis service $(\mathrm{p}<0.001)$. Also the proportion of subjects receiving intravenous thrombolysis within 60 minutes of hospital arrival improved from $21.9 \%$ in the first year of service to $70.8 \%$ in the third year. Graph 1 and 2 depict this improvement in timely administration of intravenous thrombolysis.

\section{Discussion}

Our study demonstrates that the outcomes of intravenous thrombolysis from our newly established stroke service are comparable to internationally reported data. We thrombolysed patients with moderate to severe strokes (median NIHSS 12) and the outcomes at discharge were excellent (median NIHSS 4). A total of twelve patients $(6.8 \%)$ developed symptomatic intracranial hemorrhage defined as a deterioration in NIHSS scale of four or more points associated with a bleed on repeat CT scan. Of these four died in hospital.

Table I Demographic and Risk Factor Profile of Thrombolysed patients $(n=176)$

\begin{tabular}{|c|c|}
\hline Age (years) Mean (SD) & 50.84 (14.17) Range $22-84$ \\
\hline Male (\%) & $147(83.5)$ \\
\hline \multicolumn{2}{|l|}{ Ethnicity (\%) } \\
\hline UAE Arab & $6(3.4)$ \\
\hline Non UAE Arab & $25(14.3)$ \\
\hline South Asian & $110(62.5)$ \\
\hline Caucasian & $15(8.5)$ \\
\hline Far East Asian & $18(10.2)$ \\
\hline African & $2(1.1)$ \\
\hline \multicolumn{2}{|l|}{ Income (\%) } \\
\hline Less than 25,000 AED & $132(75.0)$ \\
\hline $25-50,000$ AED & $34(19.3)$ \\
\hline Greater than 50,000 AED & $10(5.7)$ \\
\hline \multicolumn{2}{|l|}{ Education level (\%) } \\
\hline Illiterate & $57(32.4)$ \\
\hline High School & $81(46.0)$ \\
\hline University & $38(21.6)$ \\
\hline \multicolumn{2}{|l|}{ Mode of Admission (\%) } \\
\hline Via EMS & | 44 (8I.8) \\
\hline Via Non-EMS & $31(17.6)$ \\
\hline In-hospital stroke & $\mathrm{I}(0.6)$ \\
\hline \multicolumn{2}{|l|}{ Baseline Functional status (\%) } \\
\hline Independent at home & $175(99.4)$ \\
\hline Special care at home & $\mathrm{I}(0.6)$ \\
\hline \multicolumn{2}{|c|}{ Time lapse (Minutes) Median (IQR) } \\
\hline Onset to door & $80.00(60.00-115.00)$ \\
\hline Door to Emergency physician & $3.00(2.00-7.00)$ \\
\hline Door to $\mathbf{C T}$ & $20.00(\mid 3.00-30.00))$ \\
\hline Door to Neurologist & $30.00(22.50-48.50)$ \\
\hline Door to Needle & $60.00(50.00-77.00)$ \\
\hline \multicolumn{2}{|l|}{ TOAST (\%) } \\
\hline Cardioembolic & $37(21.0)$ \\
\hline
\end{tabular}

Table Continued...

\begin{tabular}{ll}
\hline Age (years) Mean (SD) & $\mathbf{5 0 . 8 4}(\mathbf{I}$ 4. I7) Range 22-84 \\
\hline Large Artery Atherothrombotic & $3 \mathrm{I}(\mathrm{I7.6)}$ \\
Small Vessel & $55(31.3)$ \\
Other determined & $6(2.8)$ \\
Undetermined & $48(27.4)$ \\
Vascular Risk Factors (\%) & \\
Hypertension & $96(54.5)$ \\
Diabetes & $43(24.4)$ \\
Dyslipidemia & $68(38.6)$ \\
Smoker & $57(32.4)$ \\
Coronary Artery Disease & $28(15.9)$ \\
Prior Stroke & $18(10.4)$ \\
Atrial fibrillation & $22(12.5)$ \\
Peripheral arterial disease & $2(1.1)$ \\
\hline
\end{tabular}

Table 2 Efficacy and Safety outcomes

\begin{tabular}{ll}
\hline Outcome & \\
\hline mRS 2 or less n (\%) & $26(14.8)$ \\
Day 0 & $102(58.0)$ \\
Day 3 & $126(71.6)$ \\
Discharge & $61(85.9)$ \\
3 months (7I) & \\
NIHSS (Median (IQR)) & $12(9-15)$ \\
Day 0 & $7(3-13)$ \\
Day 3 & $4(2-8)$ \\
Discharge & $12(6.8)$ \\
Post tpa Symptomatic Intracranial hemorrhage $\mathbf{n}(\%)$ & $12(6.8)$
\end{tabular}

In-hospital death (\%)

$12(6.8)$

Table 3 Improvement in Time components across three years

\begin{tabular}{|c|c|c|c|c|}
\hline Year & $201 \mathrm{I}-12(47)$ & $2012-13(60)$ & $2013-14(69)$ & p-value \\
\hline Door to & & & & \\
\hline $\begin{array}{l}\text { Emergency } \\
\text { Physician }\end{array}$ & $10.12(14.19)$ & $5.90(7.99)$ & $3.80(3.17)$ & 0.002 \\
\hline Door to CT & 33.00 (21.91) & $25.42(16.23)$ & $17.34(9.57)$ & $<0.001$ \\
\hline Door to NMP & $56.19(23.55)$ & $36.58(18.47)$ & 26.57 (13.58) & $<0.001$ \\
\hline Door to needle & $78.88(29.50)$ & 61.41 (22.95) & $57.22(15.94)$ & $<0.001$ \\
\hline
\end{tabular}

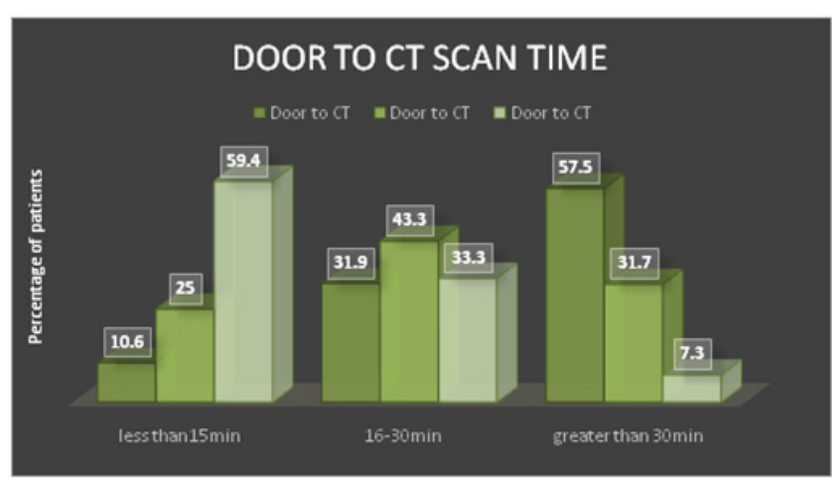

Figure I $\mathrm{N}=57$; Epidemiological distribution of the pathological fractures, traumatic fractures, and nonunion.

When comparing our results with the initial thrombolysis experience from around the world, several interesting observations can be made. Firstly, the age of stroke onset for our patients is almost two decades younger when compared to Western countries, ${ }^{13-16}$ and almost one decade younger then that reported from other Asian countries. ${ }^{17-21}$ When Arabs were analyzed separately, the median age of thrombolysed Arab patients was slightly higher (56 years) but still lower than that reported internationally. This is consistent with the 
emerging data suggesting a much younger age at stroke onset in Asian population.

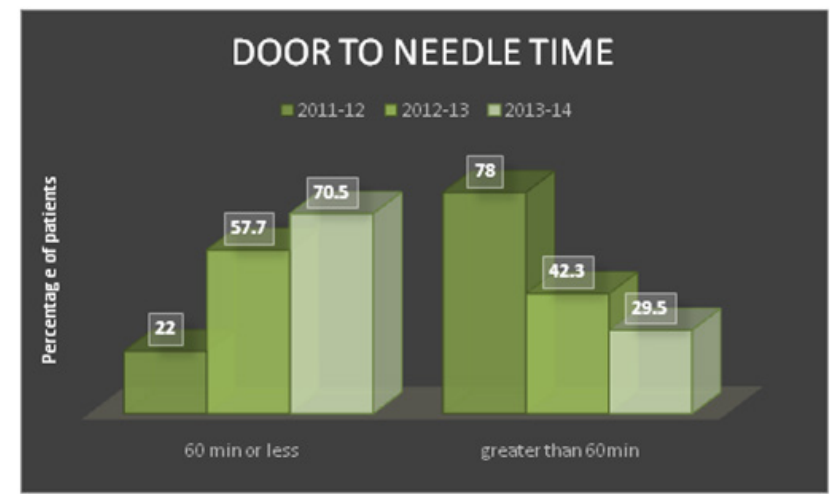

Figure $\mathbf{2}$ Improvement in Door to Needle time over three years of service.

When risk factor profiles for the thrombolysed patients were compared, we found that the proportion of hypertensive patients was almost the same as that seen in the some of the Western cohorts. However, the proportion of diabetics was higher compared to reports from other countries $\left(15 \%\right.$ in the Canadian ${ }^{13}$ and Belgian ${ }^{15}$ cohorts and $18.8 \%$ from China $^{19}$ ). When comparing Arabs to non-Arabs within our cohort, this proportion was much higher, with $45.2 \%$ Arabs reporting diabetes, $77 \%$ reporting hypertension and more than $50 \%$ reporting dyslipidemia. This is consistent with high prevalence of vascular risk factors reported from a population based study from Abu Dhabi. Atrial fibrillation was much less common in our cohort compared to international data which may be because our patient population was much younger.

The severity of stroke for our thrombolysed patients is comparable to patients from other thrombolysis registries. In the recent Asian cohort $^{22}$ the median NIHSS at presentation was 12, similar to our patients. The European and North American cohorts ${ }^{13-17}$ report a slightly higher median NIHSS.

We used the standard dose of $0.9 \mathrm{mg} / \mathrm{kg}$ alteplase for our patients. This is the dose used in the NINDS rtPA trial and all Western countries. However, as pointed out by a recent review, ${ }^{23}$ the doses used in Asia are more diverse. After the Japanese Acute Stroke Trial ${ }^{24}$ which demonstrated the efficacy of $0.6 \mathrm{mg} / \mathrm{kg}$ alteplase with fewer hemorrhagic complications, various Asian countries have adopted lower doses of alteplase for their patients. This precludes effective comparisons between various Asian cohorts. In our patients, we used the standard $0.9 \mathrm{mg} / \mathrm{kg}$ dose, and found our symptomatic ICH rates to be slightly higher than those reported from USA and UK..$^{16,17}$

The median onset to treatment time (OTT) was 145 minutes (IQR 116-190 minutes) for our thrombolysed patients. This compares very favorably with available international data on initial experiences with thrombolysis. From developed countries ${ }^{13-17}$ median OTT is reported between 140 and 155 minutes whereas much higher values are reported from Asian countries like China ${ }^{19}$ and Singapore. ${ }^{21}$ The median door to needle time for our patients was 60 minutes. When initial experiences are compared with developed Western nations as well as developing Asian countries, this figure is much lower indicating the excellent performance of our stroke service. Furthermore, we have demonstrated that since the establishment of our stroke service three years ago, each year the performance in terms of timely administration of intravenous thrombolysis is consistently getting better.

Table 4 summarizes how our results compare with thrombolysis outcomes from other developed as well as developing countries.

Table 4 Comparing Thrombolysis experience between countries

\begin{tabular}{|c|c|c|c|c|c|c|}
\hline Country & $\begin{array}{l}\text { Number of } \\
\text { patients }\end{array}$ & $\begin{array}{l}\text { Window } \\
\text { Dose }\end{array}$ & Onset to needle time & Stroke Severity & Outcome & Primary safety outcome \\
\hline $\begin{array}{l}\text { Dubai (UAE) } \\
2011-2014\end{array}$ & $\begin{array}{l}\text { Median Age } 49 \\
(40-62)\end{array}$ & $\begin{array}{l}4.5 \\
0.9 \mathrm{mg} / \mathrm{kg}\end{array}$ & $\begin{array}{l}\text { OTT I } 45 \text { (II6-190) } \\
\text { DNT } 60 \text { (IQR 50-77.5) }\end{array}$ & $\begin{array}{l}\text { NIHSS } 12 \text { at onset } \\
\text { discharge } 4\end{array}$ & & $\begin{array}{l}\mathrm{SICH} 6.8 \% \\
\mathrm{SICH} 4.6 \%\end{array}$ \\
\hline $\begin{array}{l}\text { Canada } \\
|999-200|\end{array}$ & $\begin{array}{l}\text { II } 35 \\
\text { Median age } 73\end{array}$ & $\begin{array}{l}3 \\
0.9 \mathrm{mg} / \mathrm{kg}\end{array}$ & $\begin{array}{l}\text { OTT I55 (130-I75) } \\
\text { DNT } 85(60-109.5)\end{array}$ & NIHSS I4 (9-19) & $\begin{array}{l}\text { mRS } 0-131.8 \% \\
90 \text { day mortality } \\
22.3 \%\end{array}$ & $\begin{array}{l}\text { Any clinical decline within } \\
24 \text { hours associated with } \\
\text { hemorrhage on follow up } \\
\text { CT }\end{array}$ \\
\hline $\begin{array}{l}\text { SITS MOST } \\
2002-2006^{14} \\
\text { I4 EU countries }\end{array}$ & $\begin{array}{l}6483 \\
\text { Median age } 68\end{array}$ & $\begin{array}{l}3 \\
0.9 \mathrm{mg} / \mathrm{kg}\end{array}$ & $\begin{array}{l}\text { OTT I } 40(115-165) \\
\text { DNT } 68(30)\end{array}$ & NIHSS I 2 (8-I7) & $\begin{array}{l}\text { mRS } 0-2 \text { at } 3 \\
\text { months } 54.8 \%\end{array}$ & $\mathrm{SICH} 4.6 \%$ ECASS \\
\hline $\begin{array}{l}\text { Belgium }^{15} \\
\text { 2002-2007 }\end{array}$ & $\begin{array}{l}743 \\
\text { Median age } 71\end{array}$ & $\begin{array}{l}3 \\
0.9 \mathrm{mg} / \mathrm{kg}\end{array}$ & $\begin{array}{l}\text { Median } \\
\text { OTT I40 } \\
\text { DNT } 75\end{array}$ & NIHSS I4 (9-19) & $\begin{array}{l}\text { mRS } 0-243.5 \% \text {, } \\
\text { Mortality } 23 \% \text { at } 3 \\
\text { months }\end{array}$ & $\begin{array}{l}\text { SICH } 6.9 \% \\
\text { ECASS }\end{array}$ \\
\hline $\begin{array}{l}\text { USA }^{16} \\
\text { I996-2000 }^{-200}\end{array}$ & $\begin{array}{l}269 \\
\text { Mean age } 68\end{array}$ & $\begin{array}{l}3 \\
0.9 \mathrm{mg} / \mathrm{kg}\end{array}$ & $\begin{array}{l}\text { OTT I } 37 \\
\text { DNT Mean } 70 \text { (28) }\end{array}$ & $\begin{array}{l}\text { NIHSS at onset } \\
\text { mean I4.4 (6.I) } \\
\text { At discharge } 6.6 \\
(6.9) \\
\text { Median } 3\end{array}$ & $\begin{array}{l}3 \text { month outcomes } \\
\text { not reported }\end{array}$ & $\begin{array}{l}\text { SICH } 5.6 \% \\
\text { ECASS }\end{array}$ \\
\hline $\begin{array}{l}\text { UK }^{17} \\
2002-2006\end{array}$ & $\begin{array}{l}327 \text { SITS MOST } \\
\text { Median age } 68 \\
287 \text { SITS ISTR } \\
\text { Median age } 72\end{array}$ & $\begin{array}{l}3 \\
0.9 \mathrm{mg} / \mathrm{kg}\end{array}$ & $\begin{array}{l}\text { OTT } \\
\text { Median } 155 \\
\text { OTT } \\
\text { Median } 165\end{array}$ & $\begin{array}{l}\text { NIHSS at onset } \\
\text { median } 14.5\end{array}$ & $\begin{array}{l}\text { Outcome at } 3 \mathrm{~m} \\
48 \% \mathrm{mRS} 0-2\end{array}$ & $\begin{array}{l}\mathrm{SICH} 4.8 \% \\
\text { ECASS } \\
3.2 \% \text { SITS-MOST }\end{array}$ \\
\hline $\begin{array}{l}\text { Poland } 18 \\
\text { 2003-2007 }\end{array}$ & 481 & $\begin{array}{l}3 \\
0.9 \mathrm{mg} / \mathrm{kg}\end{array}$ & $\begin{array}{l}\text { OTT Median } 160 \\
\text { DNT } 82 \text { (mean) }\end{array}$ & NIHSS Mean II & $\begin{array}{l}\text { Outcome at } 3 \mathrm{~m} \\
54 \% \mathrm{mRS} 0-2\end{array}$ & $\begin{array}{l}\text { SICH I. } 2 \% \\
\text { (SITS MOST) }\end{array}$ \\
\hline $\begin{array}{l}\text { China }{ }^{19} \\
\text { 2007-2008 }\end{array}$ & 181 & $\begin{array}{l}3 \\
56 \% \text { received } \\
0.9 \mathrm{mg} / \mathrm{kg}\end{array}$ & $\begin{array}{l}\text { OTT I80 (I50-228) } \\
\text { DNT II6 (IQR 70-I50) }\end{array}$ & \multicolumn{2}{|l|}{$\begin{array}{l}\text { NIHSS } 4-14(56.4 \%) \\
\text { NIHSS } \geq 15(29.8 \%\end{array}$} & Not reported \\
\hline
\end{tabular}


Table Continued...

\begin{tabular}{|c|c|c|c|c|c|c|}
\hline Country & $\begin{array}{l}\text { Number of } \\
\text { patients }\end{array}$ & $\begin{array}{l}\text { Window } \\
\text { Dose }\end{array}$ & Onset to needle time & Stroke Severity & Outcome & Primary safety outcome \\
\hline $\begin{array}{l}\operatorname{Iran}^{20} \\
2010-2012\end{array}$ & $\begin{array}{l}37 \\
\text { Mean age } 70.2\end{array}$ & $\begin{array}{l}4.5 \\
0.9 \mathrm{mg} / \mathrm{kg}\end{array}$ & $\begin{array}{l}\text { Onset to needle mean } 186 \\
(61)\end{array}$ & $\begin{array}{l}\text { NIHSS at onset } \\
\text { I5.4 (4.6) } \\
7 \text { day } 12.8(2.5)\end{array}$ & Not reported & $\begin{array}{l}\text { SICH } 5.4 \% \\
\text { Any hemorrhage with } \\
\text { clinical deterioration }\end{array}$ \\
\hline $\begin{array}{l}\text { Singapore } \\
2000-2008\end{array}$ & $\begin{array}{l}130 \\
\text { Mean age } 60\end{array}$ & $\begin{array}{l}3 \\
\text { Low dose }+ \\
\text { standard dose }\end{array}$ & OTT 160 median & $\begin{array}{l}\text { NIHSS at onset } 14 \\
\text { median }\end{array}$ & $\begin{array}{l}\text { mRS } 0-I \text { at } 3 \\
\text { months } \\
35 \% \text { low dose } \\
59 \% \text { standard dose }\end{array}$ & $\begin{array}{l}\text { SICH } 6.2 \% \\
\text { (ECASS) Any hemorrhage } \\
\text { with clinical deterioration } \\
\text { of NIHSS } 4 \text { or more }\end{array}$ \\
\hline $\begin{array}{l}\text { Asia }^{22} \\
\text { (South Korea, } \\
\text { China, India, } \\
\text { Singapore) } \\
\text { 2006-2008 }\end{array}$ & $\begin{array}{l}591 \\
\text { Median age } 64\end{array}$ & $\begin{array}{l}3 \\
0.9 \mathrm{mg} / \mathrm{kg}\end{array}$ & OTT I30 & NIHSS at onset 12 & $\begin{array}{l}\mathrm{mRS} 0-2 \text { at } 3 \mathrm{~m} \\
62.5 \%\end{array}$ & $\begin{array}{l}\text { SICH I.9\% } \\
\text { (SITS MOST) } \\
\text { SICH } 5.6 \% \text { (ECASS) }\end{array}$ \\
\hline $\begin{array}{l}\text { Australia }^{25} \\
\text { 2002-2008 }\end{array}$ & $\begin{array}{l}581 \\
\text { Median age } 73\end{array}$ & $\begin{array}{l}3 \\
0.9 \mathrm{mg} / \mathrm{kg}\end{array}$ & $\begin{array}{l}\text { OTT I45 (I23-I66) } \\
\text { DNT } 75 \text { (IQR 57-98) }\end{array}$ & NIHSS 13 at onset & $\begin{array}{l}\text { Outcome reported } \\
\text { as odds } \\
18.6 \% \text { mortality at } \\
3 \text { months }\end{array}$ & $\begin{array}{l}\text { 6.6\% ECASS } \\
\text { I.3\% SITS MOST }\end{array}$ \\
\hline
\end{tabular}

To the best of our knowledge, this is the first comprehensive report on thrombolysis experience and outcomes from an Arab country. We have shown that a dedicated stroke service with individuals committed to improving stroke care can achieve results comparable to any developed nation. Additionally, our data demonstrates how there is room for improvement in timely administration of rtPA if continuous reinforcement is done for the individuals involved in acute stroke care. The strength of our study also lies in the multi-ethnic origin of our patients, giving a unique comparison between various groups in terms of stroke characteristics and risk factors. Also, Thrombolysis at our center is covered by the government, so non affordability did not serve as a limitation to treatment as is the case with many developing countries.

Our study had several limitations as well. Firstly, the representation of Arabs in this cohort of thrombolysed patients was low, only $18 \%$ with the rest being expatriates working in the country. This represents the structure of the UAE population as well. Due to their relatively small numbers, conclusions from the study cannot be generalized to people of Arab origin only. Secondly, our follow-up data was also limited, with only 71 of the 162 discharged patients being accessible at 3 months. This was because following stroke, most expatriates return to their home countries. As a result, the follow-up results are biased since only those who were functionally independent and able to work stayed back in the country and those with poorer outcomes had most likely left and could not be contacted. For this reason we were unable to effectively compare our 3 month outcomes with reports from other thrombolysis registries. Yet another limitation of the study is that we have not been able to effectively evaluate the protocol violations that happened at our center and the impact that had on patient outcomes.

\section{Conclusions and recommendations}

This is the first comprehensive thrombolysis registry from an Arab country. We have reported the safety and efficacy of intravenous thrombolysis is an ethnically diverse group and have shown that our results are comparable to any developed country. We have also shown that strokes are occurring at a younger age in our population, and the prevalence of certain risk factors like diabetes needs special attention.

We feel that the Rashid hospital experience can be duplicated in other parts of the country. Keeping in view the rising incidence of cardiovascular risk factors and stroke, there is a need to set up stroke services in other hospitals across UAE, and staff needs to be trained in appropriate administration of intravenous thrombolysis.

\section{Competing interests}

The authors declare that they have no competing interests.

\section{Acknowledgments}

None.

\section{Conflicts of interest}

None.

\section{References}

1. Benamer HT, Grosset D. Stroke in Arab countries: a systematic literature review. J Neurol Sci. 2009;284(1):18-23.

2. Mehndiratta MM, Khan M, Mehndiratta P, et al. Stroke in Asia: geographical variations and temporal trends. J Neurol Neurosurg Psychiatry. 2014;85(12):1308-1312.

3. Hajat C, Harrison O, Al Siksek Z. Weqaya: a population-wide cardiovascular screening program in Abu Dhabi, United Arab Emirates. Am J Public Health. 2012;102(5):909-914.

4. Tissue plasminogen activator for acute ischemic stroke. The National Institute of Neurological Disorders and Stroke rt-PA Stroke Study Group. N Eng J Med. 333(24):1581-1587.

5. Bluhmki E, Chamorro Á, Dávalos A, et al. Stroke treatment with alteplase given $3.0-4.5 \mathrm{~h}$ after onset of acute ischaemic stroke (ECASS III): additional outcomes and subgroup analysis of a randomised controlled trial. Lancet Neurol. 2009;8(12):1095-1102.

6. Al Khathaami AM, Algahtani H, Alwabel A, et al. The status of acute stroke care in Saudi Arabia: an urgent call for action! Int J Stroke. 2011;6(1):75-76.

7. Deleu D, Inshasi J, Akhtar N, et al. Risk factors, management and outcome of subtypes of ischemic stroke: a stroke registry from the Arabian Gulf. $J$ Neurol Sci. 2011;300(1):142-147.

8. Aho K, Harmsen P, Hatano S, et al. Cerebrovascular disease in the community: results of a WHO collaborative study. Bull World Health Organ. 1980;58(1):113-130.

9. Gordon D, Bendixen B, Adams H, et al. Interphysician agreement in the diagnosis of subtypes of acute ischemic stroke Implications for clinical trials. Neurology. 1993;43(5):1021-1027.

10. Brott T, Adams H, Olinger CP, et al. Measurements of acute cerebral infarction: a clinical examination scale. Stroke. 1989;20(7):864-870. 
11. Van Swieten J, Koudstaal P, Visser M, et al. Interobserver agreement for the assessment of handicap in stroke patients. Stroke. 1988;19(5):604-607.

12. Larrue V, von Kummer R, Müller A, et al. Risk factors for severe hemorrhagic transformation in ischemic stroke patients treated with recombinant tissue plasminogen activator a secondary analysis of the European-Australasian Acute Stroke Study (ECASS II). Stroke. 2001;32(2):438-441.

13. Hill MD, Buchan AM. Thrombolysis for acute ischemic stroke: results of the Canadian Alteplase for Stroke Effectiveness Study. CMAJ. 2005;172(10):1307-1312.

14. Wahlgren N, Ahmed N, Dávalos A, et al. Thrombolysis with alteplase for acute ischaemic stroke in the Safe Implementation of Thrombolysis in Stroke-Monitoring Study (SITS-MOST): an observational study. Lancet 2007;369(9558):275-282.

15. Vanacker P, Thijs V, Peeters A, et al. The Belgian experience with intravenous thrombolysis for acute ischemic stroke. Acta Neurol Belg. 2010110(2):157-162.

16. Grotta JC, Burgin WS, El-Mitwalli A, et al. Intravenous tissue-type plasminogen activator therapy for ischemic stroke: Houston experience 1996 to 2000. Arch Neurol. 2001;58(12):2009-2013.

17. Lees K, Ford G, Muir K, et al. Thrombolytic therapy for acute stroke in the United Kingdom: experience from the safe implementation of thrombolysis in stroke (SITS) register. Qjm. 2008101(11):863-869.

18. Kobayashi A, Czlonkowska A, Ahmed N, et al. Intravenous recombinan tissue plasminogen activator for acute stroke in Poland: an analysis based on the Safe Implementation of Thrombolysis in Stroke (SITS) Registry. Acta Neurol Scand. 2010;122(4):229-236.
19. Wang Y, Liao X, Zhao X, et al. Using recombinant tissue plasminogen activator to treat acute ischemic stroke in china analysis of the results from the Chinese National Stroke Registry (CNSR). Stroke. 2011;42(6):1658-1664

20. Mehrpour M, Aghaei M, Motamed MR. Safety and feasibility of intravenous thrombolytic therapy in Iranian patients with acute ischemic stroke. Med J Islam Repub Iran. 2013;27(3):113-118.

21. Sharma VK, Tsivgoulis G, Tan JH, et al. Feasibility and safety of intravenous thrombolysis in multiethnic Asian stroke patients in Singapore. J Stroke Cerebrovasc Dis. 2010;19(6):424- 430.

22. Rha JH, Shrivastava VP, Wang Y, et al. Thrombolysis for acute ischaemic stroke with alteplase in an Asian population: results of the multicenter multinational Safe Implementation of Thrombolysis in Stroke-NonEuropean Union World (SITS-NEW). Int J Stroke. 20149(Suppl A100):93-101.

23. Sharma VK, Ng KW, Venketasubramanian N, et al. Current status of intravenous thrombolysis for acute ischemic stroke in Asia. Int J Stroke. 2011;6(6):523-530.

24. Yamaguchi T, Mori E, Minematsu K, et al. Alteplase at $0.6 \mathrm{mg} / \mathrm{kg}$ for acute ischemic stroke within 3 hours of onset Japan alteplase clinical trial (J-ACT). Stroke. 2006;37(7):1810-1815.

25. Simpson MA, Dewey HM, Churilov L, et al. Thrombolysis for acute stroke in Australia: outcomes from the Safe Implementation of Thrombolysis in Stroke registry (2002-2008). Med J Aust 2010. 2010;193(8):439-443. 